\begin{tabular}{|c|c|}
\hline 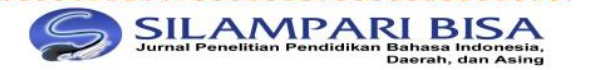 & $\begin{array}{l}\text { PRINTED ISSN: } 2620-6919 \\
\text { ONLINE ISSN: } 2620-3316\end{array}$ \\
\hline $\begin{array}{l}\text { Published by LP4MK STKIP PGRI LUBUKLINGGAU } \\
\text { Prodi Pendidikan Bahasa Indonesia, STKIP PGRI Lubuklinggau, } \\
\text { South Sumatera, Indonesia }\end{array}$ & $\begin{array}{r}\text { Vol. 1, No. 1, } 2018 \\
\text { Page: } 66-83\end{array}$ \\
\hline
\end{tabular}

\title{
KOHESI LEKSIKAL DALAM ACARA BERASAN MASYARAKAT SINDANG KELINGI MUSI RAWAS
}

\author{
Dedi $^{1}$ \& Cekman $^{2}$ \\ ${ }^{1}$ STMIK Bina Nusantara Jaya Lubuklinggau \\ ${ }^{2}$ SMK Negeri Rawas Ulu \\ Jln. Yos Sudarso No. 97 A Jawa Kanan, Kota Lubuklinggau, Sumatera Selatan \\ Telp: (0733) 322307, Fax: (0733) 322306, Indonesia \\ E-mail: dedikarwanto@gmail.com,cekmane@yahoo.com
}

Submitted: 26-May-2018 Accepted : 26-June-2018
Published: 26-June-2018
DOI: 10.31540/silamparibisa.v1i1.15

URL: https://doi.org/10.31540/silamparibisa.v1i1.15

\begin{abstract}
Abstrak
Tujuan penelitian ini secara umum untuk mendeskripsikan kohesi leksikal dalam acara Berasan masyarakat Sindang Kelingi Musi Rawas. Metode yang digunakan dalam penelitian ini adalah metode kualitatif. Data penelitian ini adalah tuturan yang terdapat dalam acara Berasan masyarakat Sindang Kelingi Musi Rawas. Sumber data yang digunakan dalam penelitian ini adalah acara Berasan masyarakat Sindang Kelingi Kabupaten Musi Rawas. Hasil penelitian ini dapat disimpulkan bahwa kohesi leksikal dalam acara Berasan masyarakat Sindang Kelingi terdapat lima aspek leksikal. Kelima aspek leksikal tersebut yaitu: 1) repetisi (pengulangan unsur wacana, kata, frasa dan klausa); 2) sinonimi (persamaan unsur wacana); 3) kolokasi (pernyataan yang berpola khusus-umum); 4) hiponimi (pernyataan yang berpola atas-bawah); dan 5) antonimi (satuan lingual yang maknanya berlawanan atau beroposisi).
\end{abstract}

Kata kunci: kohesi leksikal, wacana, acara Berasan

\section{LEXICAL COHESION IN BERASAN CEREMONIAL IN SOCIETY COMMUNITY MUSI RAWAS}

\begin{abstract}
Generally, the purpose of this study was to lexical cohesion in the Berasan ceremonial community Sindang Kelingi Musi Rawas. Specifically, this study was to determine the use of lexical cohesion Berasan ceremonial in Sindang Kelingi society at Musi Rawas. The method of this study was qualitative method. The data of this study was Berasan ceremonial which were found out in Berasan ceremonial in Sindang Kelingi society at Musi Rawas. Data source in this study was Berasan ceremonial in Sindang Kelingi Society at Musi Rawas. It can be conluded that there were five lexical aspects of Berasan ceremonial. The five lexical aspects are: (1) repetition (repetition of discourse, phrase and clause); (2) synonym (similarities of discourse element); (3) collocation (statements of specific-general pattern); (4) hiponymy (statements of top-down pattern); and (5) antonymy (lingual element which has opposite meaning).
\end{abstract}

Keywords: lexical cohesion, discourse, Berasan ceremonial 
Dedi ${ }^{1}$ \& Cekman² Kohesi Leksikal dalam Acara Berasan Masyarakat Sindang Kelingi Musi Rawas

\section{A. Pendahuluan}

Bahasa Sindang Kelingi merupakan salah satu bahasa daerah di Musi Rawas. Masyarakat yang menggunakan bahasa Sindang Kelingi tersebar di Kecamatan Terawas, Kecamatan Selangit, Kecamatan Muara Beliti, Kecamatan Tiang Pumpung Kepungut, dan Kecamatan Tuah Negeri. Bahasa Sindang Kelingi merupakan bahasa yang sering dipergunakan sebagai alat komunikasi dan interaksi sehari-hari oleh masyarakat di Musi Rawas. Bahasa Sindang Kelingi juga digunakan dalam berbagai aktivitas, misalnya dalam upacara perkawinan, upacara adat, dan proses jual beli di pasar tradisional (Noermanzah, 2017:2). Bahasa Sindang Kelingi juga digunakan dalam pergaulan antar masyarakat, musyawarah desa, slogan pemerintahan daerah, begitu juga dalam acara lamaran berasan.

Menurut Darwis dan Priyajaya (2010:2-7) dalam masyarakat Sindang Kelingi, terdapat lima tahapan sebelum perkawinan yaitu, (1) pergaulan mudamudi, (2) ngulang rasan, (3) tiang kule, (4) ngantat dendan, dan (5) belabu keje. Seiring dengan perkembangan zaman, banyak terjadi perubahan pada aspek budaya khususnya upacara perkawinan adat Sindang Kelingi. Perubahanperubahan yang terjadi bukan hanya sekedar penyederhanaan yang disebabkan pertimbangan waktu, tenaga dan biaya, tetapi penghilangan atau peniadaan tahapan sebelum perkawinan khususnya tahap kedua yaitu ngulang rasan/berasan.

Istilah berasan menurut bahasa Sindang Kelingi dapat diartikan secara luas sebagai berembug mengenai suatu urusan oleh kedua belah pihak untuk mendapatkan kesepakatan. Dalam arti yang lebih khusus, "berasan" sebagai pembicaraan kedua belah pihak untuk mendapatkan kesepakatan-kesepakatan yang berhubungan dengan proses menuju pernikahan seorang bujang dengan seorang gadis. Kegiatan dalam "berasan" untuk mencapai kesepakatan tersebut tidak terlepas dalam penggunaan bahasa Sindang Kelingi sebagai sarana interaksi dan komunikasi antara kedua belah pihak.

Menurut Djajasudarma (2012:3) wacana adalah rekaman kebahasaan yang utuh tentang peristiwa komunikasi. Komunikasi dapat menggunakan bahasa lisan 
Dedi' \& Cekman² Kohesi Leksikal dalam Acara Berasan Masyarakat Sindang Kelingi Musi Rawas dan dapat pula menggunakan bahasa tulis. Apapun bentuknya, wacana mengasumsikan adanya penyapa (addressor) dan pesapa (addressee). Dalam wacana lisan, penyapa adalah pembicara, sedangkan pesapa adalah pendengar. Dalam wacana tulis, penyapa adalah penulis sedangkan penyapa adalah pembaca. Hal ini diperjelas oleh Achmad \& Abdullah (2012:149), bahwa wacana adalah satuan bahasa yang terlengkap, yang dalam hierarki kebahasaan merupakan satuan gramatikal tertinggi dan terbesar. Wacana dapat direalisasikan dalam bentuk kata, kalimat, paragraf, atau karangan utuh (buku), yang membawa amanat lengkap. Esensi sebuah wacana tidaklah hanya dipandang sebagai satuan bahasa di atas tataran kalimat. Esensi sebuah wacana dapat dipandang dari sisi komunikasi dan dari sisi maksud komunikasi itu sendiri. Menurut Crystal (dalam Ihsan, 2011:24) wacana adalah istilah dalam linguistik yang berarti ungkapan berkelanjutan yang lebih panjang daripada sebuah kalimat.

Analisis wacana berarti penganalisaan bahasa berdasarkan konteks pemakaiannya yang mengandung unsur praktik sosial karena bahasa merupakan alat komunikasi di antara anggota masyarakat atau komunitas sosial. Menurut Stubbs (dalam Darma, 2009:3) analisis wacana merupakan suatu kajian yang meneliti dan menganalisa bahasa yang digunakan secara ilmiah, baik lisan maupun tulis. Analisa wacana menekankan kajiannya pada penggunaan bahasa dalam kontes sosial, khususnya dalam penggunaan bahasa antarpenutur. Selanjutnya, Mc Carty (dalam Ihsan, 2011:24) analisis wacana berkaitan dengan studi tentang hubungan antara bahasa dan konteks. Hal ini diperkuat dengan Sobur (2009:48) analisis wacana adalah telaah mengenai aneka fungsi bahasa. Diperjelas dengan pendapat Cook (dalam Wijaya \& Rohmadi, 2009:73) bahwa analisis wacana juga menganalisis konteks, dari aspek komunikasi seperti siapa yang mengomunikasikan, dengan siapa dan mengapa, dalam jenis khalayak dan situasi apa, melalui medium apa, bagaimana perbedaan tipe perkembangan komunikasi, dan hubungan untuk masing-masing pihak.

Berdasarkan pengertian dan pendapat di atas, analisis wacana bertujuan untuk mencari keteraturan bukan kaidah. Keteraturan yaitu hal-hal yang berkaitan dengan keberterimaan penggunaan bahasa di masyarakat secara realita dan 
Dedi ${ }^{1}$ \& Cekman² Kohesi Leksikal dalam Acara Berasan Masyarakat Sindang Kelingi Musi Rawas cenderung tidak merumuskan kaidah bahasa seperti dalam tata bahasa. Analisis wacana melibatkan hubungan unsur kohesi (unsur pembangun dari segi bentuk atau struktur lahir) dan unsur koherensi (unsur pembangun dari segi makna atau struktur batin). Segi bentuk atau struktur lahir wacana ini disebut aspek gramatikal wacana sedangkan segi makna atau struktur batin wacana disebut aspek leksikal wacana.

Kohesi leksikal ialah hubungan antar unsur dalam wacana secara semantik sedangkan kohesi gramatikal ialah hubungan antarunsur dalam wacana secara struktural (Halliday \& Hasan, 1994). Lebih lanjut, Darma (2009: 37-40) mendeskripsikan aspek gramatikal wacana mencakup pengacuan (refence), penyulihan (substitution), pelesapan (ellipsis), dan perangkaian (conjunction) sedangkan aspek leksikal mencakup repetisi (pengulangan), sinonimi (padan kata), kolokasi (sanding kata), hiponimi (hubungan atas-bawah), antonimi (lawan kata, oposisi makna), dan ekuivalensi (kesepadanan bentuk).

Fokus masalah dalam penelitian ini adalah analisis wacana dari perangkat kohesi leksikal dalam acara Berasan masyarakat Sindang Kelingi Kabupaten Musi Rawas. Analisis wacana bertujuan untuk mencari keteraturan bukan kaidah. Keteraturan yaitu hal-hal yang berkaitan dengan keberterimaan penggunaan bahasa di masyarakat secara realita dan cenderung tidak merumuskan kaidah bahasa seperti dalam tata bahasa. Penelitian tentang bahasa Sindang telah dilakukan oleh Noermanzah (2017) dengan judul "Struktur Kalimat Tunggal Bahasa Sindang di Kota Lubuklinggau dan Pengaruhnya dalam Pembelajaran Bahasa Indonesia”. Penelitian dilakukan oleh Noermanzah fokus pada kalimat tunggal Bahasa Sindang Lubuklinggau yang berpredikat verbal yang teridiri atas kalimat intransitif dan kalimat ekatransitif, kalimat tunggal berpredikat adjektival, kalimat tunggal predikat nominal, kalimat tunggal predikat numeral, kalimat tunggal berpredikat preposisional, dan kalimat tunggal adverbial. Selain itu, peneitian analisis kohesi leksikal telah dilakukan oleh Scholichah (2014) dengan judul "Analisis Kohesi Leksikal Sinonimi pada Teks Terjemahan Alquran Surah AnNahl'. Penelitian yang dilakukan oleh Sholichah ini fokus pada sinonimi. 
Dedi ${ }^{1}$ \& Cekman² Kohesi Leksikal dalam Acara Berasan Masyarakat Sindang Kelingi Musi Rawas

Dari beberapa penelitian relevan ini, menunjukkan bahwa kajian tentang kohesi leksikal dalam acara lamaran Berasan pada masyarakat Sindang Kelingi Kabupaten Musi Rawas belum dilakukan penelitian. Untuk itu, penting dilakukan penelitian dengan harapan mampu menjadi bahan pengembangan pengetahuan ilmu wacana lisan khususnya wacana lisan acara lamaran Berasan. Selain itu, dapat memberikan informasi tentang makna yang sebenarnya acara lamaran Berasan pada masyarakat Sindang Kelingi Kabupaten Musi Rawas dibangun oleh unsur kohesi leksikal.

\section{B. Metode Penelitian}

Metode yang digunakan dalam penelitian ini adalah pendekatan kualitatif dengan metode deskriptif. Sukardi (2003:162) berpendapat bahwa "penelitian deskriptif merupakan metode penelitian yang berusaha mengambarkan objek atau subjek yang diteliti sesuai dengan apa adanya, dengan tujuan mengambarkan secara sistematis fakta dan karakteristik objek yang diteliti secara tepat.

Dari pengertian di atas bahwa penelitian ini bertujuan untuk mendeskripsikan wacana dari aspek leksikal dalam wacana lamaran Berasan masyarakat Sindang Kelingi Musi Rawas. Teknik pengumpulan data merupakan suatu cara yang digunakan untuk memperoleh atau mengumpulkan data yang dibutuhkan dalam penelitian. Untuk memperoleh data yang sesuai dengan permasalahan diperlukan teknik pengumpulan data. Teknik pengumpulan data yang digunakan dalam penelitian ini, yaitu observasi dan wawancara.

Instrumen penelitian ini menggunakan panduan/kisi analisis wacana. Dalam panduan analisis wacana berdasarkan Darma (2009:40) bahwa aspek leksikal mencakup repetisi (pengulangan), sinonimi (padan kata), kolokasi (sanding kata), hiponimi (hubungan atas-bawah), antonimi (lawan kata, oposisi makna), dan ekuivalensi (kesepadanan bentuk). Analisis ini mendeskripsikan mengenai analisis wacana dari aspek leksikal Bahasa dalam acara Berasan masyarakat Sindang Kelingi Musi Rawas. Proses analisis ini difokuskan terhadap wacana dalam acara Berasan masyarakat Sindang Kelingi Musi Rawas berdasarkan dari bagian pembuka, isi, dan penutup. 
Dedi ${ }^{1}$ \& Cekman² Kohesi Leksikal dalam Acara Berasan Masyarakat Sindang Kelingi Musi Rawas

Tahapan analisis penelitian ini sebagai berikut, pertama, transkrip wacana dalam acara Berasan masyarakat Sindang Kelingi dibaca dan dipahami dalam rangka mendapatkan pemahaman kasar tentang kegiatan penelitian yang telah dilaksanakan. Kedua, seluruh wacana dalam acara Berasan yang sudah dibaca dan dipahami untuk mengetahui bagian awal wacana, isi wacana penutup wacana acara Berasan Sindang Kelingi dari aspek leksikal. Ketiga, analisis difokuskan pada aspek leksikal dari wacana acara Berasan masyarakat Sindang Kelingi. Keempat, analisis wacana acara Berasan pada masyarakat Sindang Kelingi diakhiri dengan menemukan dan menyimpulkan aspek leksikal dari wacana pada acara Berasan.

\section{Hasil Penelitian dan Pembahasan}

\section{Hasil Penelitian}

Dalam acara Berasan Masyarakat Sindang Kelingi Musi Rawas setelah dilakukan penelitian dan dianalisis, ditemukan tidak mempunyai ekuivalensi (kesepadanan bentuk). Artinya pada kondisi tertentu, unsur-unsur kohesi menjadi kontributor penting bagi terbentuknya wacana yang koheren. Namun, perlu disadari bahwa unsur-unsur kohesi tersebut tidak selalu menjamin terbentuknya wacana yang utuh dan koheren. Alasannya, pemakaian alat-alat kohesif dalam suatu teks tidak langsung menghasilkan wacana yang koheren. Berdasarkan hasil temuan, acara Berasan masyarakat Sindang Kelingi Kabupaten Musi Rawas hanya terdapat lima aspek leksikal, yaitu, 1) repitisi (pengulangan kata), 2) sinomini (padan kata), 3) kolokasi (sanding kata), 4) hiponimi (hubungan atasbawah), 5) antonimi (lawan kata, oposisi makna).

\section{Pembahasan}

Prosesi adat masyarakat Sindang Kelingi ada dua tahapan yaitu tahapan sebelum perkawinan dan tahapan adat perkawinan. Tahapan sebelum perkawinan yaitu, (1) Pergaulan Muda-Mudi, (2) Ngulang Rasan atau Berasan, (3) Tiang Kule, (4) Ngantat Dendan, (5) Belabu Keje, sedangkan tahapan adat perkawinan adalah 
Dedi ${ }^{1}$ \& Cekman² Kohesi Leksikal dalam Acara Berasan Masyarakat Sindang Kelingi Musi Rawas

(1) Nikah, (2) Tan Agung (hari memasak), (3) Pesta Malam (Deker), (4) Mapak Sedekah (resepsi), (5) Mandi Kasai.

Unsur aspek leksikal bahasa dalam acara Berasan masyarakat Sindang Kelingi, Kabupaten Musi Rawas, meliputi:

a. Repetisi

Dalam acara Berasan masyarakat Sidang Kelingi ditemukan repitisi yaitu, 37 pengulangan kata dan 7 pengulangan frasa. Repitisi yang ditemukan dalam bahasa berasan sebagai berikut.

1) "Atak ayak si atak ayak, atak ayak lorè temègè, sirih pinang ku atur dulu, atak ayak ku ngatur katè, sembah ku ngiring mangunian. Ayolah besan makan sirih, sirih kalakap pinang talang, sirih dak cukup pinang kurang, kak lah oleh Bujang Alap". (KRBA 1)

2) "Atak ayak si atak ayak, atak ayak lorè temègè, sirih pinang ku atur dulu, atak ayak ku ngatur katè, sembah ku ngiring mangunian. Ayolah besan makan sirih, sirih kalakap pinang talang, sirih dak cukup pinang kurang, kak lah oleh Bujang Alap". (KRBA 1)

3) "Atak ayak si atak ayak, atak ayak lorè temègè, sirih pinang $\underline{\mathbf{k u}}$ atur dulu, atak ayak uu ngatur katè, sembah $\underline{\mathbf{k u}}$ ngiring mangunian. Ayolah besan makan sirih, sirih kalakap pinang talang, sirih dak cukup pinang kurang, kak lah oleh Bujang Alap". (KRBA 1)

4) "Atak ayak si atak ayak, atak ayak lorè temègè, sirih pinang ku atur dulu, atak ayak ku ngatur katè, sembah ku ngiring mangunian. Ayolah besan makan sirih, sirih kalakap pinang talang, sirih dak cukup pinang kurang, kak lah oleh Bujang Alap". (KRBA 1)

Wacana tersebut menunjukkan pengulangan unsur wacana yang dipentingkan beberapa kali secara langsung. Dalam hal ini, 1) kata sirih diulang 4 kali secara langsung, 2) kata pinang diulang 3 kali secara langsung, 3) kata ku diulang 3 kali secara langsung, 4) frasa atak ayak diulang 4 kali secara langsung. Pada KRBA 1 ditemukan 3 pengulangan kata dan 1 pengulangan frasa.

5) “Kami kak adè semajè, menurut kabar dari sang Bujang kami, di uma kak adè Dèhè, kabar a Bujang ngan Dehè kak la bebusik, begurau ngan Dehè, ulasa la lamè bebusik adè katè sepakat, Bujang kami nak minang Dehè hikak". (KRBA 2)

Silampari Bisa: Jurnal Penelitian Pendidikan Bahasa Indonesia, Daerah, dan Asing Vol. 1, No. 1, 2018 
Dedi ${ }^{1}$ \& Cekman² Kohesi Leksikal dalam Acara Berasan Masyarakat Sindang Kelingi Musi Rawas

6) "Kami kak adè semajè, menurut kabar dari sang Bujang kami, di uma kak adè Dèhè, kabar a Bujang ngan Dehè kak la bebusik, begurau ngan Dehè, ulasa la lamè bebusik adè katè sepakat, Bujang kami nak minang Dehè hikak”.(KRBA 2)

7) “Kami kak adè semajè, menurut kabar dari sang Bujang kami, di uma kak adè Dèhè, kabar a Bujang ngan Dehè kak la bebusik, begurau ngan Dehè, ulasa la lamè bebusik adè katè sepakat, Bujang kami nak minang Dehè hikak". (KRBA 2)

8) "Kami kak adè semajè, menurut kabar dari sang Bujang kami, di uma kak adè Dèhè, kabar a Bujang ngan Dehè kak la bebusik, begurau ngan Dehè, ulasa la lamè bebusik adè katè sepakat, Bujang kami nak minang Dehè hikak". (KRBA 2)

9) “Kami kak adè semajè, menurut kabar dari sang Bujang kami, di uma kak adè Dèhè, kabar a Bujang ngan Dehè kak la bebusik, begurau ngan Dehè, ulasa la lamè bebusik adè katè sepakat, Bujang kami nak minang Dehè hikak'.(KRBA 2)

10) "Kami kak adè semajè, menurut kabar dari sang Bujang kami, di uma kak adè Dèhè, kabar a Bujang ngan Dehè kak la bebusik, begurau ngan Dehè, ulasa la lamè bebusik adè katè sepakat, Bujang kami nak minang Dehè hikak". (KRBA 2)

Wacana di atas menunjukkan pengulangan unsur wacana beberapa kali secara langsung yaitu, 5) kata kami diulang 3 kali secara langsung, 6) kata kabar diulang 2 kali secara langsung, 7) kata bujang diulang 3 kali secara langsung, 8) kata dehe diulang 4 kali secara langsung, 9) kata la diulang 2 kali secara langsung, dan 10) frasa kak de 2 kali diulang secara langsung. Dalam KRBA 2 ditemukan 4 pengulangan kata dan 1 pengulangan frasa.

11) Ku nih dak yu jawab a, katè adè kalu cul, katè cul kalu adè, aku nak nanyè dai yang bersangkutan. (KRDA 2)

12) Ku nih dak yu jawab a, katè adè kalu cul, katè cul kalu adè, aku nak nanyè dai yang bersangkutan. (KRDA 2)

13) Ku nih dak yu jawab a, katè adè kalu cul, katè cul kalu adè, aku nak nanyè dai yang bersangkutan. (KRDA 2)

14) Ku nih dak yu jawab a, katè adè kalu cul, katè cul kalu adè, aku nak nanyè dai yang bersangkutan. (KRDA 2)

Wacana berasan pada KRDA 2 ditemukan 2 kali pengulangan secara langsung yaitu, 11) kata kate, 12) kata ade, 13) kata kalu, 14) kata cul. 
Dedi ${ }^{1}$ \& Cekman² Kohesi Leksikal dalam Acara Berasan Masyarakat Sindang Kelingi Musi Rawas

15) Bedègur goru di ulu, ikan bemakan di Muara Tekum, ikak ku tegur dulu nilèk nga nyesal mpung lum. Yang manè dehè kak idup tekepèr debedèk banyak, awak besat banyak kekendak, sebab beban kak behat takut nilèk bujang kak sak ditengah jalan. lyè ngecas naik tebing, iyè ngicing nyebrang ayo, takut nilèk tuh rugi kecèwè bujang tullah. Sebekal dak di ulu, sebekal ditepian tullah, nyesal dak dulu nyesal datang kemudian tullah. Jadi GAN kami balèk kudai, supayo bujang bepikir atau betimbang abis-abis'(KRDI 3)

16) Bedègur goru di ulu, ikan bemakan di Muara Tekum, ikak ku tegur dulu nilèk nga nyesal mpung lum. Yang manè dehè kak idup tekepèr debedèk banyak, awak besat banyak kekendak, sebab beban kak behat takut nilèk bujang kak sak ditengah jalan. (KRDI 3)

17) Bedègur goru di ulu, ikan bemakan di Muara Tekum, ikak ku tegur dulu nilèk nga nyesal mpung lum. Yang manè dehè kak idup tekepèr debedèk banyak, awak besat banyak kekendak, sebab beban kak behat takut nilèk bujang kak sak ditengah jalan. (KRDI 3)

18) Bedègur goru di ulu, ikan bemakan di Muara Tekum, ikak ku tegur dulu nilèk nga nyesal mpung lum. Yang manè dehè kak idup tekepèr debedèk banyak, awak besat banyak kekendak, sebab beban kak behat takut nilèk bujang kak sak ditengah jalan. lyè ngecas naik tebing, iyè ngicing nyebrang ayo, takut nilèk tuh rugi kecèwè bujang tullah. Sebekal dak di ulu, sebekal ditepian tullah, nyesal dak dulu nyesal datang kemudian tullah. Jadi GAN kami balèk kudai, supayo bujang bepikir atau betimbang abis-abis'. (KRDI 3)

19) Iyè ngecas naik tebing, iyèngicing nyebrang ayo, takut nilèk tuh rugi kecèwè bujang tullah. Sebekal dak di ulu, sebekal ditepian tullah, nyesal dak dulu nyesal datang kemudian tullah. Jadi GAN kami balèk kudai, supayo bujang bepikir atau betimbang abis-abis'. (KRDI 3)

20) Sebekal dak di ulu, sebekal ditepian tullah, nyesal dak dulu nyesal datang kemudian tullah. Jadi GAN kami balèk kudai, supayo bujang bepikir atau betimbang abis-abis. (KRDI 3)

21)Yang manè dehè kak idup tekepèr debedèk banyak, awak besat banyak kekendak, sebab beban kak behat takut nilèk bujang kak sak ditengah jalan. lyè ngecas naik tebing, iyè ngicing nyebrang ayo, takut nilèk tuh rugi kecèwè bujang tullah. Sebekal idak di ulu, sebekal ditepian tullah, nyesal idak dulu 
Dedi ${ }^{1}$ \& Cekman² Kohesi Leksikal dalam Acara Berasan Masyarakat Sindang Kelingi Musi Rawas nyesal datang kemudian tullah. Jadi GAN kami balèk kudai, supayo bujang bepikir atau betimbang abis-abis. (KRDI 3)

22) Bedègur goru di ulu, ikan bemakan di Muara Tekum, ikak ku tegur dulu nilèk nga nyesal mpung lum. Sebekal idak di ulu, sebekal ditepian tullah, nyesal idak dulu nyesal datang kemudian tullah. Jadi GAN kami balèk kudai, supayo bujang bepikir atau betimbang abis-abis. (KRDI 3)

23) Sebekal idak di ulu, sebekal ditepian tullah, nyesal idak dulu nyesal datang kemudian tullah. Jadi GAN kami balèk kudai, supayo bujang bepikir atau betimbang abis-abis. (KRDI 3)

24) Bedègur goru di ulu, ikan bemakan di Muara Tekum, ikak ku tegur dulu nilèk nga nyesal mpung lum. Yang manè dehè kak idup tekepèr debedèk banyak, awak besat banyak kekendak, sebab beban kak behat takut nilèk bujang kak sak ditengah jalan. lyè ngecas naik tebing, iyè ngicing nyebrang ayo, takut nilèk tuh rugi kecèwè bujang tullah. Sebekal idak di ulu, sebekal ditepian tullah, nyesal idak dulu nyesal datang kemudian tullah. Jadi GAN kami balèk kudai, supayo bujang bepikir atau betimbang abis-abis'(KRDI 3)

25) Yang manè dehè kak idup tekepèr debedèk banyak, awak besat banyak kekendak, sebab beban kak behat takut nilèk bujang kak sak ditengah jalan. lyè ngecas naik tebing, iyè ngicing nyebrang ayo, takut nilèk tuh rugi kecèwè bujang tullah. (KRDI 3)

Wacana pada KRDI 3, ditemukan 9 pengulangan kata dan 2 pengulangan frasa. Adapun pengulangan tersebut yaitu, 15) kata dulu diulang 2 kali secara langsung, 16) kata kak dengan diulang 3 kali secara langsung, 17) kata banyak diulang sebanyak 2 kali, 18) kata bujang diulang 2 kali, 19) kata iye diulang 2 kali secara langsung, 20) kata dak diulang 2 kali, 21) kata tullah diulang 2 kali, 22) kata nyesal diulang 3 kali secara langsung, 23) kata sebekal diulang 2 kali secara langsung, 24) frasa di ulu diulang 2 kali, dan 25) frasa takut nilek diulang 2 kali.

26) Yè cam kak, yang mane bujang la ngatè atak kami brèkat segalè titik tampung kami hanggup, bujang dak sak tengah jalan dan pulè iyè dak ngecas naèk tebing dan dak pulè ngicing nyebrang ayo. Ujè bujang, wang mengukir bebarisbaris, mengukir sebatang kayu jati, bujang lah bepikir abis-abis, iye dak nyesal nyatuk mati. Kapung mang kapung serè, kapung jelatang lebat buah, kami dak 
Dedi ${ }^{1}$ \& Cekman² Kohesi Leksikal dalam Acara Berasan Masyarakat Sindang Kelingi Musi Rawas ngundè gan balèk, kami datang hakikat kami nak nambah. (Kemudian GAN dikembalikan lagi kepada Ketua Rasan Dehe). (KRBI 3)

27) Yè cam kak, yang mane bujang la ngatè atak kami brèkat segalè titik tampung kami hanggup, bujang dak sak tengah jalan dan pulè iyè dak ngecas naèk tebing dan dak pulè ngicing nyebrang ayo. Ujè bujang, wang mengukir bebarisbaris, mengukir sebatang kayu jati, bujang lah bepikir abis-abis, iye dak nyesal nyatuk mati. (KRBI 3)

28) Yè cam kak, yang mane bujang la ngatè atak kami brèkat segalè titik tampung kami hanggup, bujang dak sak tengah jalan dan pulè iyè dak ngecas naèk tebing dan dak pulè ngicing nyebrang ayo. Ujè bujang, wang mengukir bebarisbaris, mengukir sebatang kayu jati, bujang lah bepikir abis-abis, iye dak nyesal nyatuk mati. Kapung mang kapung serè, kapung jelatang lebat buah, kami dak ngundè gan balèk, kami datang hakikat kami nak nambah. (Kemudian GAN dikembalikan lagi kepada Ketua Rasan Dehe). (KRBI 3)

29) Yè cam kak, yang mane bujang la ngatè atak kami brèkat segalè titik tampung kami hanggup, bujang dak sak tengah jalan danpulè iyè dak ngecas naèk tebing dan dak pulè ngicing nyebrang ayo. (KRBI 3)

30) Yè cam kak, yang mane bujang la ngatè atak kami brèkat segalè titik tampung kami hanggup, bujang dak sak tengah jalan dan pulè iyè dak ngecas naèk tebing dan dak pulè ngicing nyebrang ayo. (KRBI 3)

31) Ujè bujang, wang menqukir bebaris-baris, menqukir sebatang kayu jati, bujang lah bepikir abis-abis, iye dak nyesal nyatuk mati. (KRBI 3)

32) Kapung mang kapung serè, kapung jelatang lebat buah, kami dak ngundè gan balèk, kami datang hakikat kami nak nambah. (Kemudian GAN dikembalikan lagi kepada Ketua Rasan Dehe). (KRBI 3)

33) Yè cam kak, yang mane bujang la ngatè atak kami brèkat segalè titik tampung kami hanggup, bujang dak sak tengah jalan dan pulè iyè dak ngecas naèk tebing dan dak pulè ngicing nyebrang ayo. Ujè bujang, wang mengukir bebarisbaris, mengukir sebatang kayu jati, bujang lah bepikir abis-abis, iye dak nyesal nyatuk mati. Kapung mang kapung serè, kapung jelatang lebat buah, kami dak ngundè gan balèk, kami datang hakikat kami nak nambah. (Kemudian GAN dikembalikan lagi kepada Ketua Rasan Dehe). (KRBI 3)

34) Yè cam kak, yang mane bujang la ngatè atak kami brèkat segalè titik tampung kami hanggup, bujang dak sak tengah jalan dan pulè iyè dak ngecas naèk 
Dedi ${ }^{1}$ \& Cekman² Kohesi Leksikal dalam Acara Berasan Masyarakat Sindang Kelingi Musi Rawas

tebing dan dak pulè ngicing nyebrang ayo. Ujè bujang, wang mengukir bebarisbaris, mengukir sebatang kayu jati, bujang lah bepikir abis-abis, iye dak nyesal nyatuk mati. (KRBI 3)

Pengulangan Wacana pada KRBI 3 yaitu, 26) kata kami diulang 5 kali, 27) kata bujang diulang 3 kali, 28) kata dak diulang 5 kali, 29) kata dan diulang 2 kali, 30) Kata pule diulang 2 kali secara langsung, 31) kata mengukir diulang 2 kali secara langsung, 32) kata kapung diulang 2 kali secara langsung, 33) kata bujang diulang 4 kali, dan 34) frasa iye dak diulang 2 kali. Jadi KRBI 3 ditemukan 8 pengulangan kata dan 1 pengulangan frasa.

35) Kalu dak nyesal gi, rasan kak nih adè perjanjian. Jadi perjanjian tuh, hatu di ako anak due pintaan (Sen, behas, ayam, niyo dll) ketigè mas kawin, kalu nga hanggup pintaan tuh, rasan kak jadi, kalu dak hanggup dak yu kite jadi a. (KRDI 4)

36) Kalu dak nyesal gi, rasan kak nih adè perjanjian. Jadi perjanjian tuh, hatu di ako anak due pintaan (Sen, behas, ayam, niyo dll) ketigè mas kawin, kalu nga hanggup pintaan tuh, rasan kak jadi, kalu dak hanggup dak yu kite jadi a. (KRDI 4)

37) Kalu dak nyesal gi, rasan kak nih adè perjanjian. Jadi perjanjian tuh, hatu di ako anak due pintaan (Sen, behas, ayam, niyo dll) ketigè mas kawin, kalu nga hanggup pintaan tuh, rasan kak jadi, kalu dak hanggup dak yu kite jadi a. (KRDI 4)

38) Kalu dak nyesal gi, rasan kak nih adè perjanjian. Jadi perjanjian tuh, hatu di ako anak due pintaan (Sen, behas, ayam, niyo dll) ketigè mas kawin, kalu nga hanggup pintaan tuh, rasan kak jadi, kalu dak hangqup dak yu kite jadi a. (KRDI 4)

39) Kalu dak nyesal gi, rasan kak nih adè perjanjian. Jadi perjanjian tuh, hatu di ako anak due pintaan (Sen, behas, ayam, niyo dll) ketigè mas kawin, kalu nga hanggup pintaan tuh, rasan kak jadi, kalu dak hanggup dak yu kite jadi a. (KRDI 4)

40) Kalu dak nyesal gi, rasan kaknih adè perjanjian. Jadi perjanjian tuh, hatu di ako anak due pintaan (Sen, behas, ayam, niyo dll) ketigè mas kawin, kalu nga hanggup pintaan tuh, rasan kak jadi, kalu dak hanggup dak yu kite jadi a. (KRDI 4) 
Dedi ${ }^{1}$ \& Cekman² Kohesi Leksikal dalam Acara Berasan Masyarakat Sindang Kelingi Musi Rawas

Pengulangan wacana pada KRDI 4 yaitu, 35) kata perjanjian diulang 2 kali, 36) kata jadi diulang 3 kali, 37) kata pintaan diulang 2 kali, 38) kata hanggup diulang 2 kali, 39) frasa kalu dak diulang 2 kali, 40) frasa rasan kak diulang 2 kali. Jadi KRDI 4 ditemukan 4 pengulangan kata dan 2 pengulangan frasa.

41) Kedatangan kami, bak rèbèsè tuh, kapak hekali lukè duè, kami nak nyerah hembah hujud, supayo yè kak tau keluarge dehe tuh, mane metuè, ipo tuè, nenek, wak, bibi, mamang dan yang lain-lain a. (KRBP 5)

42) Kedatangan kami, bak rèbèsè tuh, kapak hekali lukè duè, kami nak nyerah hembah hujud, supayo yè kak tau keluarge dehe $\underline{\text { tuh }}$, mane metuè, ipo tuè, nenek, wak, bibi, mamang dan yang lain-lain a. (KRBP 5)

Wacana di atas (KRBP 5) pengulangan kata yaitu, 41) kata kami diulang 2 kali, dan 42) kata tuh diulang 2 kali. Ditemukan 2 kali pengulangan unsure wacana di KRBP 5.

43) Kak penyuluh dari kami, kalu kelam mintèk diterang, kalu kusut mintèk dilesai, kalu condong mintèk ditegakkan. (KRBP 6)

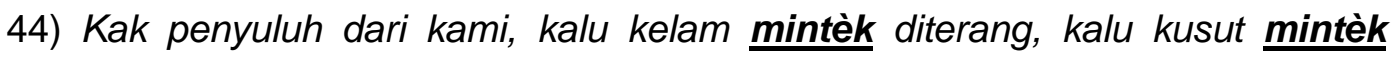
dilesai, kalu condong mintèk ditegakkan. (KRBP 6)

Pengulangan wacana pada KRBP 6 yaitu, 43) kata kalu diulang 3 kali secara langsung, dan 44) kata mintek diulang 3 kali secara langsung.

b. Sinonimi

Sinonimi adalah hubungan semantik yang menyatakan adanya kesamaan makna antara satu satuan ujaran dengan satuan ujaran lainnya. Sinonim yang ditemukan dalam bahasa kegiatan berasan masyarakat Sindang Kelingi yaitu,

(1) Bebusik dan bergurau (teman akrab) (KRBA 2) "Kami kak adè semajè, menurut kabar dari sang Bujang kami, di uma kak adè Dèhè, kabar a Bujang ngan Dehè kak la bebusik, begurau ngan Dehè, ulasa la lamè bebusik adè katè sepakat, Bujang kami nak minang Dehè hikak'. (KRBA 2)

(2) Dehe dan Awak (Gadis) (KRDI 3)

Yang manè dehè kak idup tekepèr debedèk banyak, awak besat banyak kekendak, sebab beban kak behat takut nilèk bujang kak sak ditengah jalan. (KRDI 3)

(3) Sak dan nyesal (Menyesal) (KRDI 3) dan (KRBI 3) 
Dedi ${ }^{1}$ \& Cekman² Kohesi Leksikal dalam Acara Berasan Masyarakat Sindang Kelingi Musi Rawas

Bedègur goru di ulu, ikan bemakan di Muara Tekum, ikak ku tegur dulu nilèk nga nyesal mpung lum. Yang manè dehè kak idup tekepèr debedèk banyak, awak besat banyak kekendak, sebab beban kak behat takut nilèk bujang kak sak ditengah jalan. (KRDI 3)

Bujang dak sak tengah jalan dan pulè iyè dak ngecas naèk tebing dan dak pulè ngicing nyebrang ayo. Ujè bujang, wang mengukir bebaris-baris, mengukir sebatang kayu jati, bujang lah bepikir abis-abis, iye dak nyesal nyatuk mati. (KRBI 3)

(4) Bepikir dan betimbang (berpikir) (KRDI 3)

Jadi GAN kami balèk kudai, supayo bujang bepikir atau betimbang abisabis. (KRDI 3)

(5) lyè ngecas naik tebing dg iyè ngicing nyebrang ayo, (mengeluh) (KRDI 3) dan (KRBI 3)

lyè ngecas naik tebing, iyè ngicing nyebrang ayo, takut nilèk tuh rugi kecèwè bujang tullah. (KRDI 3)

pulèiyè dak ngecas naèk tebing dan dak pulè ngicing nyebrang ayo. (KRBI 3)

(6) Nyesal dak dulu dan nyesal kemudian tullah, (penyesalan di akhir) (KRDI 3)

Sebekal idak di ulu, sebekal ditepian tullah, nyesal idak dulu nyesal datang kemudian tullah. (KRDI 3)

(7) Kalu kelam mintèk diterang dan kalu kusut mintèk dilesai dan kalu condong mintèk, (mohon pembinaan dan pengarahan). (KRBP 6)

Kak penyuluh dari kami, kalu kelam mintèk diterang, kalu kusut mintèk dilesai, kalu condong mintèk ditegakkan. (KRBP 6)

Pada wacana bahasa berasan Sindang kelingi ditemukan 5 sinonim kata dan 4 sinonim klausa.

c. Kolokasi

Kolokasi adalah asosiasi tertentu dalam menggunakan pilihan kata dan kata tersebut cenderung digunakan secara berdampingan (bersanding). Dalam wacana pada acara Berasan masyarakat Sindang Kelingi Musi Rawas ditemukan 
Dedi ${ }^{1}$ \& Cekman² Kohesi Leksikal dalam Acara Berasan Masyarakat Sindang Kelingi Musi Rawas kolokasi yaitu, 1) bebusik dan begurau, 2) rugi kecewe, 3) bepikir dan betimbang, dan 4) hembah dan sujud.

(1) Bebusik dan bergurau (teman Akrab). (KRBA 2) "Kabar a Bujang ngan Dehè kak la bebusik, bequrau ngan Dehè. (KRBA 2)

(2) Rugi kecewe (Kecewa). (KRDI 3) lyè ngecas naik tebing, iyè ngicing nyebrang ayo, takut nilèk tuh rugi kecèwè bujang tullah. (KRDI 3)

(3) Bepikir atau betimbang (Berpikir). (KRDI 3)

Jadi GAN kami balèk kudai, supayo bujang bepikir atau betimbang abisabis. (KRDI 3)

(4) Hembah hujud (Salam mohon restu) (KRDI 3)

Kedatangan kami, bak rèbèsè tuh, kapak hekali lukè duè, kami nak nyerah hembah hujud, (KRBP 5)

d. Hiponimi

Hiponimi dapat diartikan sebagai satuan bahasa (kata, frase, kalimat) yang maknanya dianggap bagian dari makna satuan lingual yang mencakup beberapa unsur atau satuan yang berhiponim. Hiponimi yang ditemukan dalam acara Berasan Sindang Kelingi yaitu:

(1) Sak ditengah jalan. lyè ngecas naik tebing, iyè ngicing nyebrang ayo (Menyesal ditengah jalan. Dia mengeluh naik tebing, dia angkat sepan menyembrang air). (KRDI 3) dan (KRBI 3)

Sebab beban kak behat takut nilèk bujang kak sak ditengah jalan. Iyè ngecas naik tebing, ivè ngicing nyebrang ayo, takut nilèk tuh rugi kecèwè bujang tullah. (KRDI 3)

Yè cam kak, yang manè bujang la ngatè atak kami brèkat segalè titik tampung kami hanggup, bujang dak sak tengah jalan dan pulè ivè dak ngecas naèk tebing dan dak pulè ngicing nyebrang ayo. ( $K R B / 3)$

(2) Pintaan (sen, behas, ayam, niyo dll) (permintaan, uang, beras, ayam, kelapa dan lain-lain). (KRDI 4)

Kalu dak nyesal gi, rasan kak nih adè perjanjian. Jadi perjanjian tuh, hatu di ako anak due pintaan (Sen, behas, ayam, niyo dII) ketigè mas kawin, kalu nga hanggup pintaan tuh, rasan kak jadi, kalu dak hanggup dak yu kite jadi a. (KRDI 4) 
Dedi ${ }^{1}$ \& Cekman² Kohesi Leksikal dalam Acara Berasan Masyarakat Sindang Kelingi Musi Rawas

(3) Keluarga, metuè, ipo tuè, nenek, wak, bibi, mamang (Keluarga, mertua, kakak ipar, kakek dan nenek, uwak, bibi, paman). (KRBP 5)

Kedatangan kami, bak rèbèsè tuh, kapak hekali lukè duè, kami nak nyerah hembah hujud, supayo yè kak tau keluarge dehe tuh, mane metuè, ipo tuè, nenek, wak, bibi, mamang dan yang lain-lain a. (KRBP 5)

e. Antonimi

Antonimi merupakan salah satu jenis aspek leksikal wacana dengan cara mengoposisikan makna unsur yang satu dengan unsur yang lain. Antonim yang ditemukan dalam wacana acara Berasan yaitu:

(1) cukup dan kurang (cukup dan kurang). (KRBA 1)

Ayolah besan makan sirih, sirih kalakap pinang talang, sirih dak cukup pinang kurang, kak lah oleh Bujang Alap". (KRDA 1)

(2) Bujang dan dehe (pemuda dan gadis). (KRBA 2) dan (KRDI 3)

Kami kak adè semajè, menurut kabar dari sang Bujang kami, di uma kak adè Dèhè, kabar a Bujang ngan Dehè kak la bebusik, begurau ngan Dehè, ulasa la lamè bebusik adè katè sepakat, Bujang kami nak minang Dehèhikak". (KRBA 2)

Yang manè dehè kak idup tekepèr debedèk banyak, awak besat banyak kekendak, sebab beban kak behat takut nilèk bujang kak sak ditengah jalan. lyè ngecas naik tebing, iyè ngicing nyebrang ayo, takut nilèk tuh rugi kecèwè bujang tullah. (KRDI 3)

(3) sepakat dan meminang (sepakat dan belum sepakat). (KRBA 2)

"Kami kak adè semajè, menurut kabar dari sang Bujang kami, di uma kak adè Dèhè, kabar a Bujang ngan Dehè kak la bebusik, begurau ngan Dehè, ulasa la lamè bebusik adè katè sepakat, Bujang kami nak minang Dehè hikak". (KRBA 2)

(4) katè adè kalu cul dan katè cul kalu adè, (dikatakan ada kalau tidak ada, dikatakan tidak ada kalau ada) (KRDA 2)

Ku nih dak yu jawab a, katè adè kalu cul, katè cul kalu adè, aku nak nanyè dai yang bersangkutan (KRDA 2)

(5) ikak dan nilèk(sekarang dan nanti) (KRDI 3)

Bedègur goru di ulu, ikan bemakan di Muara Tekum, ikak ku tegur dulu nilèk nga nyesal mpung lum. (KRDI 3)

(6) datang dan balek (datang dan pulang). (KRDI 3) dan (KRBI 3)

Silampari Bisa: Jurnal Penelitian Pendidikan Bahasa Indonesia, Daerah, dan Asing Vol. 1, No. 1, 2018 
Dedi \& Cekman² Kohesi Leksikal dalam Acara Berasan Masyarakat Sindang Kelingi Musi Rawas

Sebekal dak di ulu, sebekal ditepian tullah, nyesal idak dulu nyesal datang kemudian tullah. Jadi GAN kami balèkkudai, supayo bujang bepikir atau betimbang abis-abis. (KRDI 3)

Kapung mang kapung serè, kapung jelatang lebat buah, kami dak ngundè gan balèk, kami datang hakikat kami nak nambah. (Kemudian GAN dikembalikan lagi kepada Ketua Rasan Dehe). (KRBI 3)

\section{Simpulan}

Berdasarkan hasil penelitian dan pembahasan pada acara Berasan masyarakat Sindang Kelingi Kabupaten Musi Rawas dapat disimpulkan bahwa terdapat lima aspek kohesi leksikal, yaitu: 1) repetisi (pengulangan unsur wacana, kata, frasa dan klausa), 2) sinonimi (persamaan unsur wacana), 3) kolokasi (pernyataan yang berpola khusus-umum), 4) hiponimi (pernyataan yang berpola atas-bawah), dan 5) antonomi (satuan lingual yang maknanya berlawanan atau beroposisi). Kelima aspek kohesi leksikal tersebut mampu membangun wacana lisan pada acara Berasan atau lamaran masyarakat Sindang Kelingi Kabupaten Musi Rawas menjadi sebuah komunikasi lisan antara pihak keluarga calon pengantin laki-laki dengan pihak keluarga pengantin wanita. Komunikasi kedua belak pihak keluarga tersebut bertujuan mendapatkan kesepakatan-kesepakatan berkaitan proses menuju pernikahan.

\section{Daftar Pustaka}

Achmad HP \& Abdullah, Alek. (2012). Linguistik Umum. Jakarta: Erlangga.

Darma, Yoce Aliah. (2009). Analisis Wacana Kritis. Bandung: CV Yrama Widya.

Darwis \& Priyajaya, Sabda. (2010). Tata Cara Adat Perkawinan Sukubangsa Linggau di Sumatera Selatan. Palembang: Dinas Pendidikan Sumatera Selatan.

Djajasudarma, T. Fatimah. (2012). Analisis dan Pragmatik. Bandung: PT Refika Aditama.

Halliday, M A K \& Hasan R. (1994). Bahasa Konteks dan Teks: Aspek-Aspek Bahasa dalam Pandangan Semiotik Sosial. Yogyakarta: Gajah Mada University Press.

Silampari Bisa: Jurnal Penelitian Pendidikan Bahasa Indonesia, Daerah, dan Asing 
Dedi ${ }^{1}$ \& Cekman² Kohesi Leksikal dalam Acara Berasan Masyarakat Sindang Kelingi Musi Rawas

Ihsan, Diemroh. (2011). Pragmatik, Analisis Wacana, dan Guru Bahasa. Palembang: Universitas Sriwijaya.

Noermanzah, N. (2017). Struktur Kalimat Tunggal Bahasa Sindang di Kota Lubuklinggau dan Pengaruhnya dalam Pembelajaran Bahasa Indonesia. AKSIS: Jurnal Pendidikan Bahasa dan Sastra Indonesia, 1(1), 2. doi:10.21009/aksis.010101

Sholichah, Ery. (2014). Analisis Kohesi Leksikal Sinonimi pada Teks Terjemahan Alquran Surah An-Nahl. Skripsi, Fakultas Keguruan dan Ilmu Pendidikan Universitas Muhammadiyah Surakarta. Diakses pada 1 Oktober 2017. http://eprints.ums.ac.id/28562/17/NASKAH_PUBLIKASI.pdf

Sobur, Alex. (2009). Analisis Teks Media. Bandung: PT Remaja Rosdakarya.

Sukardi. (2003). Metodologi Penelitian Pendidikan. Jakarta: PT Bumi Aksara.

Wijana, I Dewa Putu \& Rohmadi, Muhammad. (2009). Analisis Wacana Pragmatik: Kajian Teori dan Analisis. Surakarta: Yuma Pustaka. 